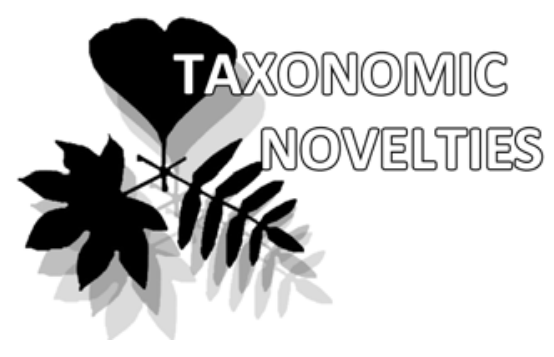

\title{
Two new species of Schistochilopsis (Scapaniaceae, Hepaticae) from North-West Pacific and the key to Schistochilopsis taxa in the Pacific Asia
}

\author{
Vadim A. Bakalin* \& Ksenia G. Klimova
}

Vadim A. Bakalin*

e-mail: vabakalin@gmail.com

Ksenia G. Klimova

e-mail: ksenia.g.klimova@mail.ru

Botanical Garden-Institute FEB RAS, Vladivostok, Russia

* corresponding author

Manuscript received: 22.09.2016 Review completed: 19.10.2016

Accepted for publication: 10.11.2016

Published online: 18.11.2016

\begin{abstract}
A B S T R A C T
Two new species of Schistochilopsis are described from the easternmost Pacific Russia (Kamchatka and Kurils). S. obscura Bakalin sp. nov. is characterized by 'lophozioid' appearance, relatively large trigones in leaf cells and few in number oil bodies per midleaf cell. S. pacifica is distinguished by golden brownish pigmentation of apical segment of shoots, relatively few in number biconcentric oil bodies and leaves with entire margins.
\end{abstract}

K e y w o r d s : Hepaticae, Schistochilopsis, taxonomy, oil bodies, Pacific, East Asia

\section{P E 3 Ю M E}

Бакалин В.А., КАимова К.Г. Ава новых вида Schistochilopsis (Scapaniaceae, Hepaticae) из северо-западной Пацифики и кмюч дмя определения Schistochilopsis в притихоокеанской Азии. Ава новых вида Schistochilopsis описаны из самых восточных районов российской Пацифики (Камчатка и Курилы). S. obscura Bakalin sp. nov. характеризуется мофозиоидным внешним обликом, относительно крупными угловыми утолщениями кАеток Аистьев и немногочисленными масляными тельцами в клетках средней части миста. S. pacifica отличает золотисто-коричневатая пигментация апикальных сегментов побегов, сравнительно немногочисленные масляные тельца со среАинной капелькой и цельнокрайние Аистья.

Ки ючевые скиова: Hepaticae, Schistochilopsis, таксономия, масляные тельца, Восточная Азия

\section{N T RODUCTION}

The genetic researches on Schistochilopsis in its older sense (= Massula Schljakov n. illeg.) has revealed the polyphyletic nature of the entity and resulted in segregation Heterogemma (Jørg.) Konstant. \& Vilnet for taxa with ellipsoidal (without protruding angles as in remained taxa) gemmae (Konstantinova \& Vilnet 2009). The rest cluster of taxa, although monophyletic in generic sense, includes along with morphologically and genetically well defined species also the highly polymorphic entity that may be called as $S$. opacifolia-incisa complex. The genetic distances in the latter complex highly exceed the distances between different species in other clades (Vilnet et al. 2008). In our opinion this result evidences the poor understanding of the real taxonomic diversity within complex and some new taxa should be revealed that will make the species concept and taxa 'comparability' in the complex more sound. Unrelated to the latter speculation we found several populations of peculiar Schistochilopsis in Kamchatka Peninsula and Iturup Island (South Kurils) that although superficially similar to the members of S. opacifolia-incisa complex, but bear some specific traits in oil-bodies, coloration and leaf features and should be regarded as new, previously undescribed species. The description and discussion of the latter taxa is the main goal of the present account.

\section{MATERIAL AND METHODS}

The basic task of the present work was to evaluate correlation of minor morphological and ecological differences in populations of the same/different taxa with differences in oil bodies parameters (structure, size, number, etc.). For this purpose we studied over than 100 specimens of Schistochilopsis collected in the 2015 in Kamchatka Peninsula and the Kurils. All studied specimens were photographed for both macro-morphological (general appearance) and cytological (leaf cell oil bodies) features. After, both groups of features were compared in the series of studied specimens and several 'natural' groups were recognized those then were coordinated with recognized species. At least two series were found as belong to previously not recognized taxa those are described below. All studied herbarium specimens are in VBGI, whereas the photographs are owned by Laboratory of Cryptogamic Biota center for micromorphological researches of the Botanical Garden-Institute FEB RAS. 


\section{TAXONOMIC TREATMENT}

\section{Schistochilopsis obscura Bakalin sp. nov.}

Description. Plants prostrate to ascending, pale greenish to almost salad green, in well exposed places with light golden coloration near shoot apices, merely soft, 5-10 mm long and 1.2-1.8 $\mathrm{mm}$ wide. Rhizoids numerous, colorless to grayish, forming dense to loose mat under the stem or obliquely to erect spreading in unclear fascicles. Stem nearly straight, pale greenish, ventral side similar in color to dorsal one, sparsely laterally branched, transversely elliptic in the cross section, $150-200 \times 230-300 \mu \mathrm{m}$, with moderately thickened walls, moderate in size, concave trigones, irregularly and in various portions of the cross section infested by fungal hyphae. Leaves contiguous to nearly subimbricate and loosely enclosed one to another, subtransversely inserted, loosely sheathing the stem in the base, canaliculate, obliquely spreading above, widely obliquely ovate to nearly trapezoidal or subquadrate, divided by widely $\gamma$ - or U-shaped sinus descending to $1 / 4-2 / 5$ of leaf length into two unequal, triangular, sometimes with attenuate apex lobes, 500-950×550-950 $\mu \mathrm{m}$, unistratose to base. Midleaf cells subisodiametric or shortly oblong, thin-walled, 22 $40 \times 20-35 \mu \mathrm{m}$, trigones moderate in size, convex; cuticle smooth to weakly striolate. Gemmae abundant in some plants, 2-celled, 4-5-gonal, with slightly protrudent angles, $17-22 \times 17-20 \mu \mathrm{m}$, united in tiny clusters in apices of apical leaves lobes. Dioicous. Gynoecia terminal, with 1 subfloral innovation; bracts equally or nearly so trilobed, sinus $\gamma$-shaped, with slightly recurved basal part, lobes gibbous; bracteole widely lanceolate, not connate with bracts. (Otherwise not seen). (Fig. 1: A-C, 2)
Holotype: RUSSIA. SAKhalin Province, middle part of Iturup Island, Goryachaya River upper course (4504'40"N 14759'13"E), $200 \mathrm{~m}$ alt. Leg. V.A. Bakalin 19 September 2015. Forest belt (lighted Larix-Betula ermanii with dense Sasa understory community) near to timberline. Moist open cliffs above steaming hot water with high sulfur content (K-79-18-15, VBGI).

Paratype: RUSSIA. SakHalin Province, middle part of Iturup Island, Goryachaya River upper course $\left(45^{\circ} 04^{\prime} 40^{\prime \prime N}\right.$ $\left.147^{\circ} 59^{\prime} 13^{\prime \prime E}\right), 200 \mathrm{~m}$ alt. Leg. V.A. Bakalin 19 September 2015 (K-79-21-15, VBGI). Virtually the same site with holotype, at the distance ca. 10 meters upstream of the latter.

Comment. By general appearance this species has habit of Lophozia s. str., rather than Schistochilopsis due to almost uniformly bilobed leaves and a few, large and granulate oil bodies. However, such features as: 1) no difference in coloration of ventral and dorsal sides of the stem, 2) very polymorphous sinus (strongly varying even within one shoot), 3) absence of well defined microcellous layer in the stem cross section confirm its position within Schistochilopsis rather than in Lophozia. Within Schistochilopsis the species is related to Schistochilopsis opacifolia-incisa complex. The basic differences from the latter are: 1) leaves unistratose to base (also rare in some phases of S. incisa and S. cornuta), 2) stable bilobed leaves, 3) few, granulate oil bodies, 4) lobe apices without prominent cells (also in some phases of S. opacifolia).

The ecology of the species may be poorly understood due to limited material. The species was collected over moist cliffs wetted by steaming water with high content of sulphuric acid and a lot of $\mathrm{SO}_{2}$ mixed with $\mathrm{H}_{2} \mathrm{O}$ steam. The habitat is free of snow cover for the winter and never
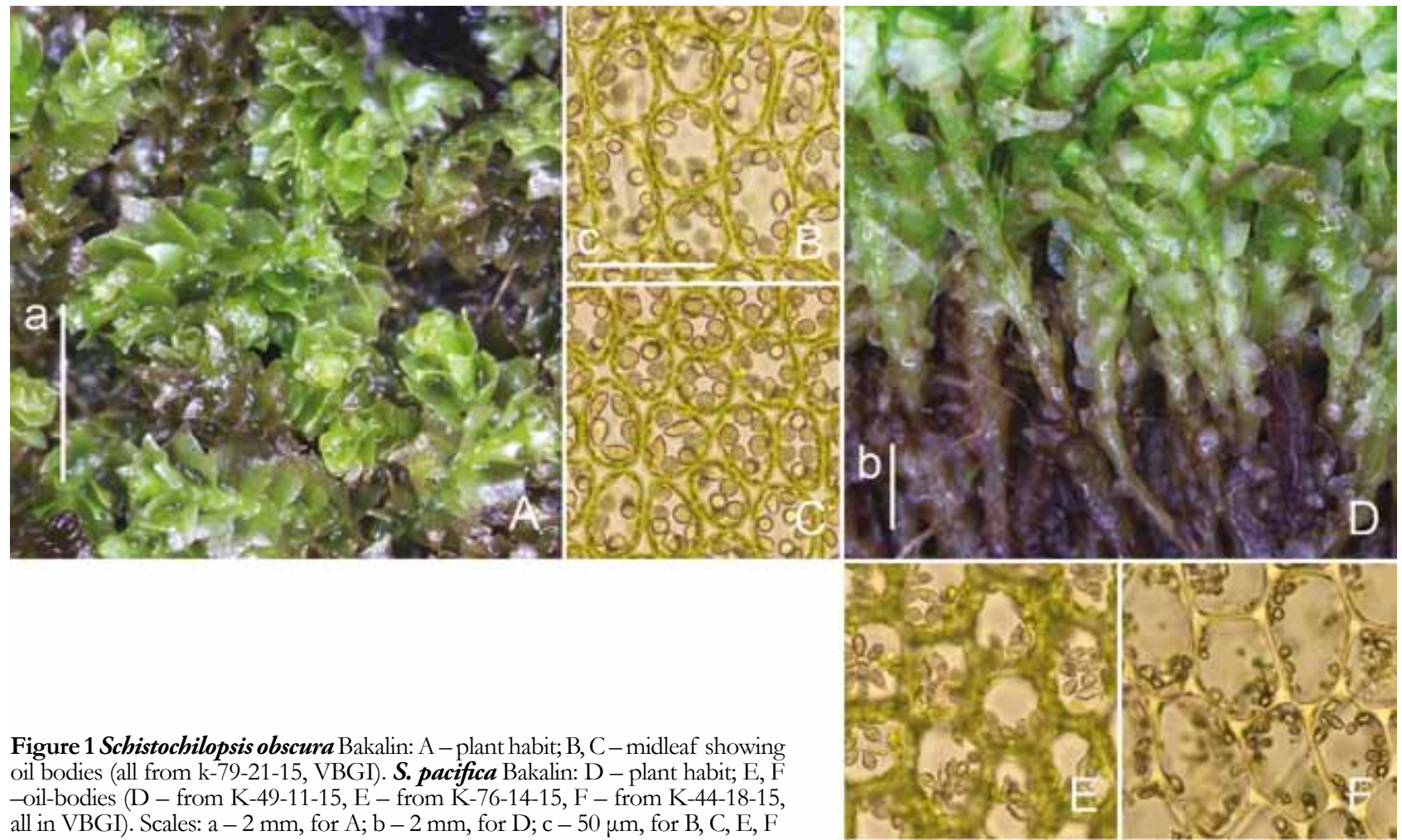

Figure 1 Schistochilopsis obscura Bakalin: A - plant habit; B, C - midleaf showing oil bodies (all from k-79-21-15, VBGI). S. pacifica Bakalin: D - plant habit; E, F -oil-bodies (D - from K-49-11-15, E - from K-76-14-15, F - from K-44-18-15, all in VBGI). Scales: $\mathrm{a}-2 \mathrm{~mm}$, for $\mathrm{A} ; \mathrm{b}-2 \mathrm{~mm}$, for $\mathrm{D} ; \mathrm{c}-50 \mu \mathrm{m}$, for B, C, E, F 


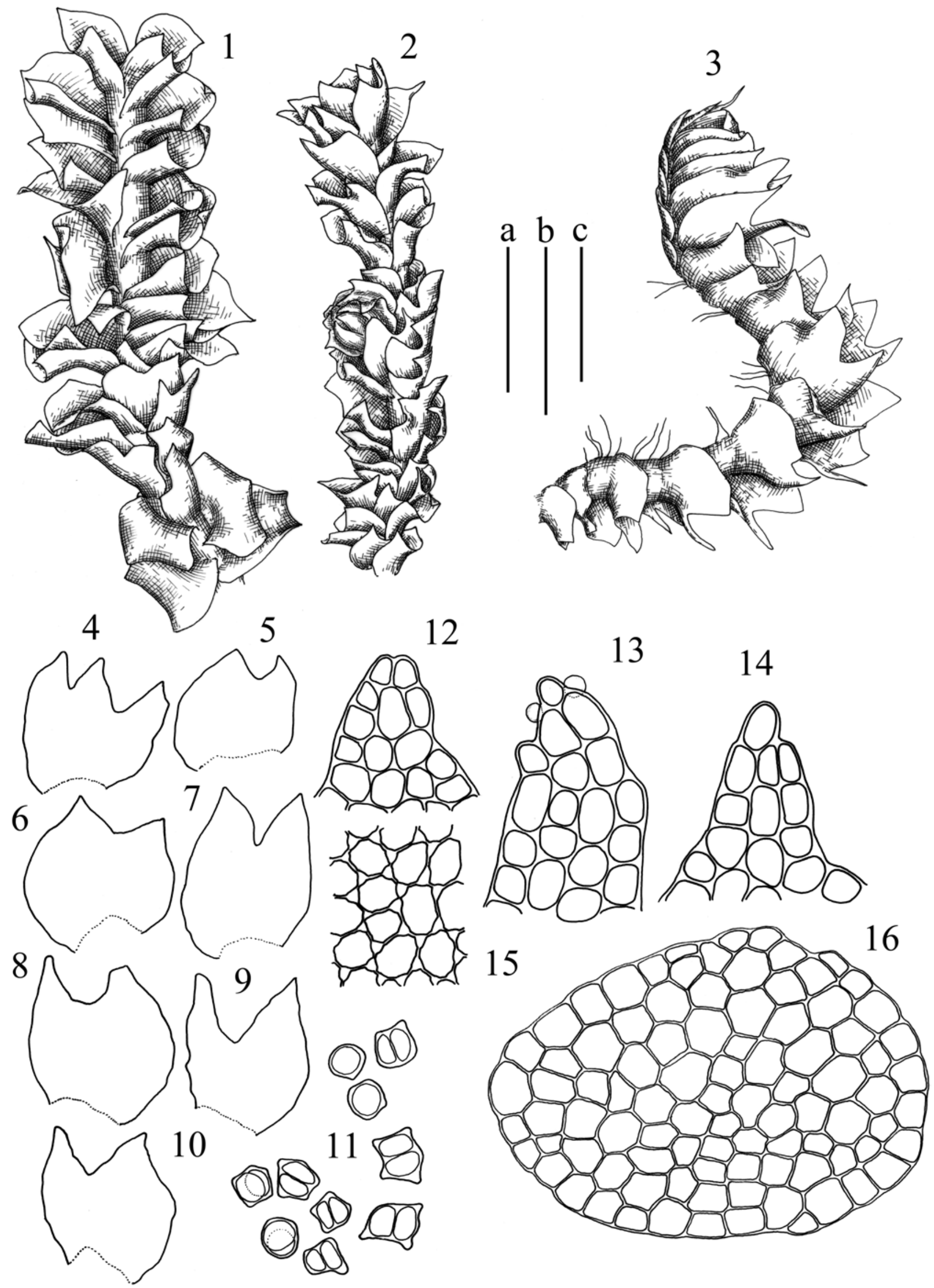

Figure 2 Schistochilopsis obscura Bakalin: 1 - plant habit, dorsal view; 2 - perianthous (with juvenile perianth) plant habit, dorsal view; 3 - plant habit, lateral view; 4-10 - leaves; 11 - gemmae; 12-14 - lobe apices; 15 - midleaf cells; 16 - stem cross section (all from K-79-18-15, VBGI). Scales: $\mathrm{a}-1 \mathrm{~mm}$, for $1-3 ; \mathrm{b}-1 \mathrm{~mm}$, for $4-10 ; \mathrm{c}-150 \mu \mathrm{m}$, for $11, \mathrm{c}-100 \mu \mathrm{m}$, for $12-16$ 
freezing, with the temperature of the substratum varying between $+2{ }^{\circ} \mathrm{C}$ (February) and $+20^{\circ} \mathrm{C}$ (August). The stream where the species was collected is surrounded by the community of controversial nature. The tree 'level' is composed of the mixture of Larix kurilensis Mayer and Betula ermanii Cham. (thus boreal taxa), whereas the understory is composed of dense Sasa spp. with some scattered dwarf plants of Taxus cuspidata Siebold et Zucc. ex Endl., with well developed Gaultheria miqueliana Takeda and Ilex crenata Thunb. (taxa cool to warm temperate in origin). Some rocky substrata (also those where the type was collected) are under open canopy of Pinus pumila (Pall.) Regel. (rather Hemiarctic shrub). Schistochilopsis obscura formed pure mats or was intermixed with Marsupella tubulosa Steph., Nardia subclavata (Steph.) Amakawa and Kurzia makinoana (Steph.) Grolle. Two former are distinctly 'insular' East Asian and are not known in the continent (with the exception of southern part of Korean Peninsula). Kurzia makinoana has more wide range, although throughout of its distribution it prefers the areas under influence of oceanic air masses. We think the newly described taxon may belong to the group of oceanic East Asian hemiboreal element and may be expected in similar or other constantly moistened habitats southward (e.g. Kunashir Island and Hokkaido).

\section{Schistochilopsis pacifica Bakalin sp. nov.}

Description. Plants ascending to erect in dense patches, very lax and soft, pale greenish to whitish, with characteristically golden brownish colored apices, 15-30 mm long and (1.2-)2.0-3.0 mm wide. Rhizoids colorless, strongly flexuous, obliquely spreading, sparse to virtually absent. Stem sparsely laterally branched, transversely elliptic in the cross section, $350-600 \mu \mathrm{m}$ high and 500-800 $\mu \mathrm{m}$ wide, cells in the cross section very thin-walled, with small to vestigial trigones, 5-7-gonal, 20-38 $\mu \mathrm{m}$ in diameter, becoming smaller and with slightly thickened walls to the outer margin. Leaves distant, rarely (near apex) contiguous, obliquely to almost subtransversely inserted, for $1 / 5-2 / 3$ of the stem width decurrent ventrally and for $1 / 3-3 / 2$ decurrent dorsally, slightly concave, with coarsely undulate margin or loosely sheathing the stem, nearly transversely elliptic to trapezoidal, 1000-1700×1000-2500 $\mu \mathrm{m}$, divided by widely $\gamma$ - to $\mathrm{V}$-shaped or semicrescentic sinus descending to $1 / 5-2 / 5$ of leaf length into 2-3 triangular, unequal, rarely with attenuate tip lobes. Underleaves virtually absent or (rarely, mostly near apices) present, spatulate to widely lanceolate, $1 / 2-2 / 3$ of leaf length. Midleaf cells $30-62 \times 30-45 \mu \mathrm{m}$, thin-walled, with moderate in size or (rarely in plants from shaded habitats) small, concave trigones; cuticle smooth to weakly striolate; leaves bi-tristratose in lower $1 / 5-1 / 4$ of the length or unistratose to base (smaller leaves). Gemmae 2-celled, 4-5-gonal, 20-26×20-24 $\mu \mathrm{m}$, with slightly protruding angles. Dioicous. Gynoecia with 1 subfloral innovation, bracts 3-4-lobed, with deep (to 1/2 of leaf length), $\gamma$-shaped, recurved in basal part sinus; bracteole widely lanceolate, ca. $1 / 2$ of bract length. Androecia intercalary, with 2-3 pairs of bracts, bracts unequally trilobed, slightly inflate in the base; antheridia 3-4 per bract, nearly spherical, 150-200 $\mu \mathrm{m}$ in diameter, stalk biseriate, ca. $50 \mu \mathrm{m}$ long. (Otherwise unknown). (Fig. 1: D-F, 3, 4: A-G).

Holotype: RUSSIA. KamchatKa Territory. East Kamchatka, Ganalsky Range, Bakening volcano area, upper course of Pravaya Kamchatka River, western slope of Bakening volcano $\left(53^{\circ} 54^{\prime} 58^{\prime \prime} \mathrm{N} 158^{\circ} 01^{\prime} 27^{\prime \prime} \mathrm{E}\right), 1065 \mathrm{~m}$ alt. Leg. Vadim A. Bakalin 6 August 2015. Subalpine belt, on moist boulder near stream (K-49-20-15, VBGI).

Paratypes: RUSSIA. KamchatKa Territory. East Kamchatka, Ganalsky Range, Bakening volcano area, upper course of Pravaya Kamchatka River, western slope of

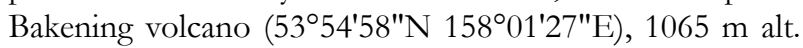
Leg. Vadim A. Bakalin 6 August 2015 (K-49-16-15, K-4911-15, VBGI; NB: virtually the same site and habitat with holotype with the difference of position within 10-20 meters from holotype); the same, (535 $\left.56^{\prime} 45^{\prime \prime} \mathrm{N} 158^{\circ} 01^{\prime} 56^{\prime \prime E}\right)$, $900 \mathrm{~m}$ alt. Leg. Vadim A. Bakalin 4 August 2015, moist sand near temporary stream in alpine belt (K-44-18-15, VBGI); East Kamchatka, upper course of Nalycheva River, near Pinachevsky Pass (53²6'31"N 158 39'08"E), $900 \mathrm{~m}$ alt. Leg. Vadim A. Bakalin 19 August 2015, alpine belt, moist boulder near stream (K-67-4-15, VBGI); Sakhalin Province, northern part of Iturup Island, Medvezhiya Bay, Medvezhiya River middle course $\left(45^{\circ} 29^{\prime} 27^{\prime \prime N} 148^{\circ} 49^{\prime} 06^{\prime \prime E}\right)$, $530 \mathrm{~m}$ alt. Leg. V.A. Bakalin 16 September 2015, subalpine belt, moist cliff in snowbed (K-76-14-15, VBGI); the same, Medvezhiya Bay, Nival'nyy Stream Upper course (4529'46"N 14849'31"E), 750 m alt. Leg. V.A. Bakalin 16 September 2015, alpine belt, moist soil near stream (K-7715-15, VBGI).

Comment. Superficially this species is similar to Schistochilopsis opacifolia s. str. (Fig. 4: $\mathrm{H}-\mathrm{K}$ ) and occupies similar habitats. However, even in the field, the patches of S. pacifica markedly differs in golden brownish coloration of patches (due to coloration of apical part of the shoots). In Kamchatka both species sometimes growing along the same bank of stream and form differently colored, sometimes adjacent patches (forming mixed cushions as exception). The following features help to separate two taxa: 1) entire margin of leaf lobes in $S$. pacifica (versus commonly variously dentate, although without prominently acute and apically thickened cell as that ending teeth in $S$. incisa), 2) presence of golden brownish coloration persistent in drying (versus plants absolutely free of secondary pigmentation, commonly becoming grayish green to even blackish in drying in S. opacifolia), 3) irregular presence of large underleaves in robust sterile shoots in $S$. pacifica (versus virtually total absence), 4) few in number, granulate and mostly biconcentric oil bodies (versus oil bodies numerous, mostly smoothsurfaced and commonly nonbiconcentric in S. opacifolia).

Figure 3 Schistochilopsis pacifica Bakalin: 1, 2-plant habit; 3-gemmae; 4, 5-bracts; 6-11 - leaves; 12, 13 - leaf base, longitudinal section; 14, 15 - stem cross section, fragment; 16 - midleaf cells (all from K-49-20-15, VBGI). Scales: $\mathrm{a}-2 \mathrm{~mm}$, for 1, 2; $\mathrm{b}-50 \mu \mathrm{m}$, for 3; c - 2 mm, for 4-11; d $200 \mu \mathrm{m}$, for 12-15; e $-100 \mu \mathrm{m}$, for 16 


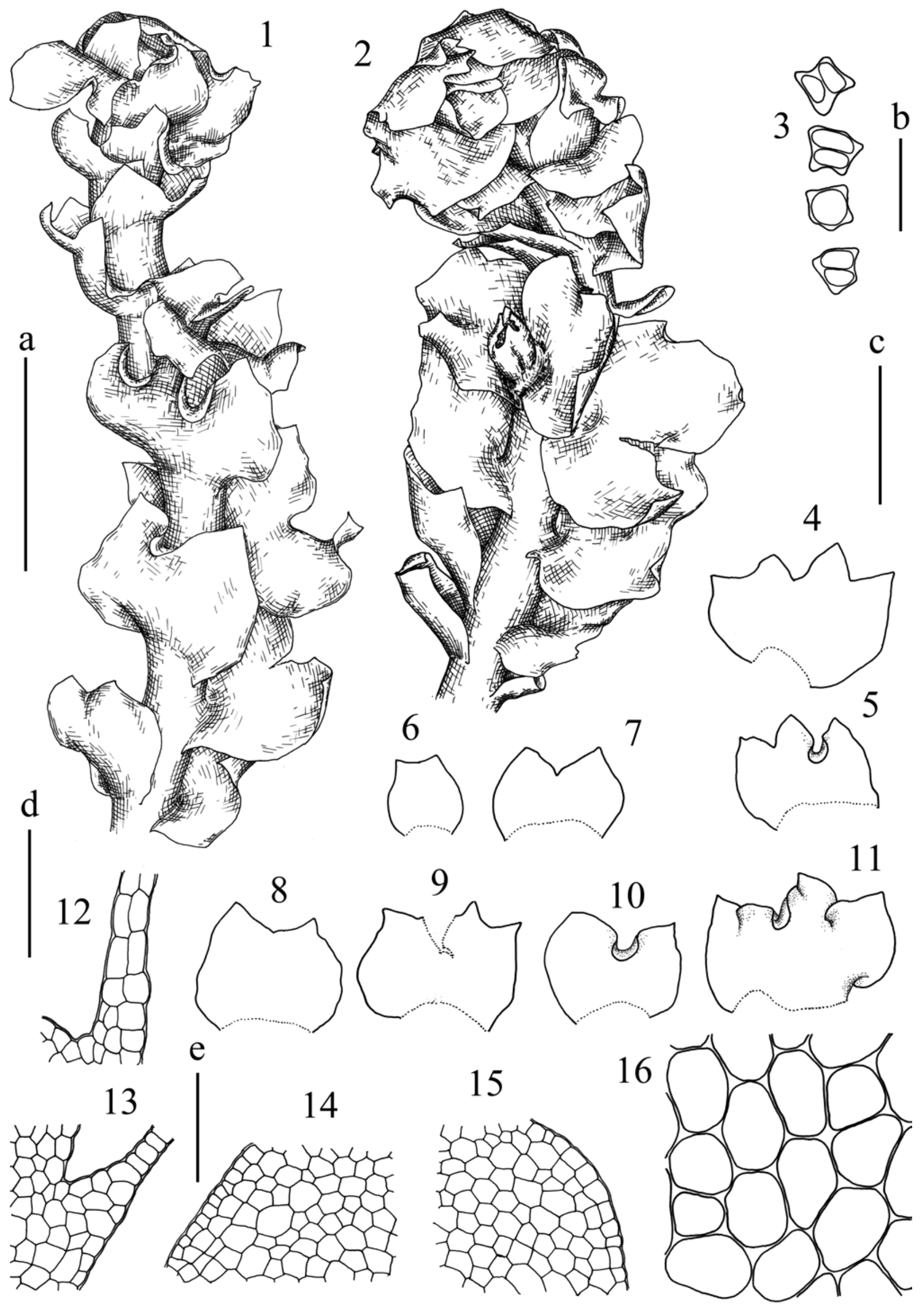



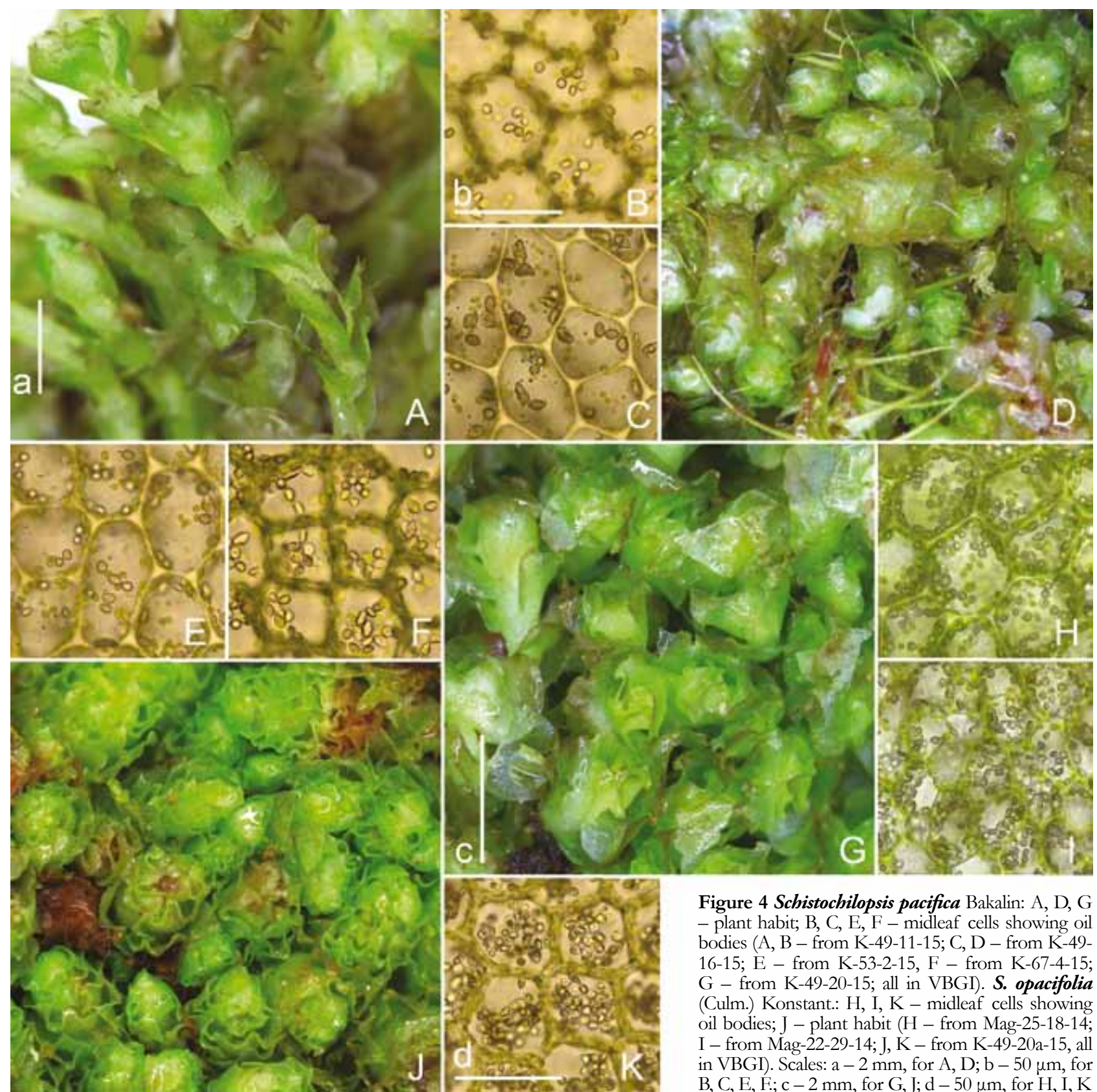

Figure 4 Schistochilopsis pacifica Bakalin: A, D, G - plant habit; B, C, E, F - midleaf cells showing oil bodies (A, B - from K-49-11-15; C, D - from K-4916-15; E - from K-53-2-15, F - from K-67-4-15; G - from K-49-20-15; all in VBGI). S. opacifolia (Culm.) Konstant.: H, I, K - midleaf cells showing oil bodies; J - plant habit ( $\mathrm{H}$ - from Mag-25-18-14; I - from Mag-22-29-14; J, K - from K-49-20a-15, all in VBGI). Scales: $\mathrm{a}-2 \mathrm{~mm}$, for $\mathrm{A}, \mathrm{D} ; \mathrm{b}-50 \mu \mathrm{m}$, for B, C, E, F.; c $-2 \mathrm{~mm}$, for G, J; d $-50 \mu \mathrm{m}$, for H, I, K

At present Schistochilopsis pacifica is known from two areas in East Kamchatka and from northern part of Iturup Island of the South Kurils. In all localities the species is attached to subalpine ( $=$ crooked forest) to alpine ( $=$ mountain tundra) belts of the mountains situated in Hemiarctic to Boreal zones. All localities are in the areas under oceanic or hyperoceanic climate dominating with rather smoothened seasonal temperature variations and regular atmospheric moisturizing of landscapes. The species grow on acidic substrata, like stones of sandy soil along streams aside of regular impact of running water, although probably flooded in snow-melting season. If to generalize the area of $S$. pacifica, it may be called as Hemiarctic montane East Asian. We expect wider, than it is currently known, occurrence of the species in Eastern Kamchatka and Kuril Island Chain and (probably) some areas in eastern coast of Hokkaido.
Since there are not the keys for Pacific Asia that would include all taxa of Schistochilopsis in its current sense we provide the corresponding key that also includes taxa of Heterogemma as superficially similar to Schistochilopsis and may be mistaken with the latter.

\section{Key to Schistochilopsis taxa in Pacific Asia}

1. Ventral side of the stem (at least in older parts) purplebrown to black-purple colored, distinctly different in color

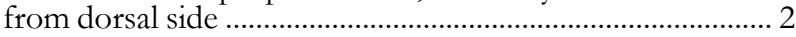

1. Ventral side of stem whitish, greenish to brownish or green, not sharply different in color from dorsal side ......... 3

2. Gemmae smooth, plants green to yellowish (with the exception of brown purple coloration of ventral side of the stem), pellucid, leaves distant until very near to the apex, midleaf cells up $50 \mu \mathrm{m}$ long, tiny isolated plants among Sphagnum ...... [Heterogemma laxa (Lindb.) Konstant. et Vilnet (Amphi-oceanic, nearly Hemiarctic)]. 
2. Gemmae with prominently protruding angles, plants always with red or purplish tint, leaves distant in lower part of shoots, but commonly contiguous to subimbricate in its upper half, not pellucid, midleaf cells often up to $60-80 \mu \mathrm{m}$ long, robust plants of bare peat and fine soil

.... Schistochilopsis grandiretis (Lindb. ex Kaal.) Konstant. (Arctic to Hemiarctic, also montane, subcircumpolar).

3.Leaveswithwelldeveloped wing(veryobviousatleastinlarger leaves) ........... Schistochilopsis cornuta (Steph.) Konstant. (Hemiboreal to cool temperate, also montane, East Asian).

3. Leaves without wing 4

4. Gemmae 1-celled, smooth (ellipsoidal, commonly with 'mamilla' in one end); midleaf cells commonly exceed 40$45 \mu \mathrm{m}$ wide; oil bodies numerous (15-40 per midleaf cell), nonbiconcentric; plants commonly pale to whitish, but with purplish to purple coloration commonly present in shoot apices in plants from exposed places

.. [Heterogemma capitata (Hook.) Konstant. et Vilnet (Amphi-Oceanic Boreal to Cool Temperate)]

4. Gemmae (1-)2-celled, angular with obviously (although sometimes not strongly) protrudent angles; midleaf cells mostly less than $40-45 \mu \mathrm{m}$ wide; oil bodies $4-40$ per midleaf cell, if more than 15 per cell then at least some oil bodies are biconcentric; plants greenish to green and greenish yellowish, never whitish, never with purplish pigmentation (although sometimes with golden brownish pigmentation present)

5. Leaf lobe apices terminated by strongly elongated ( 2 and more times longer than wide) cell with thickened apex ....... 6

5. Leaf lobes terminated not by strongly elongate cell (apical cell mostly less than 1.5 times as long as wide) ............... 8

6. Leaves almost fixedly bilobed, sinus commonly less than $1 / 5-1 / 4$ of leaf length, leaf margin with many additions large (3-10 celled at the base) teeth that in combination with short sinus looks as multi-lobed, leaves distant to contiguous Schistochilopsisnakanishi(H.Inoue) Konstant. (Oro-temperate, Taiwanese).

6. Leaves variously $2-3$-lobed, with sinus $1 / 4-1 / 3$ of leaf length, leaf margin with teeth less than 3 cells wide or entire

7. Upper leaves of the shoot densely toothed, with needle-like hyaline teeth with end cell $120-200 \mu \mathrm{m}$ long .............................. Schistochilopsis setosa (Mitt.) Konstant.

(Himalaya and its Eastern spoors to northern Indo-China).

7. Upper leaves of the shoot not or sparsely to densely toothed, teeth acute, mostly chlorophyllose, end cell of ordinary tooth 30-50 $\mu \mathrm{m}$ long, end cell of apical lobe tooth to $100 \mu \mathrm{m}$ long .................... Schistochilopsis incisa (Schrad.) Konstant. (Arctic to Boreal circumpolar).
8. Stem nearly two or more times wider than thick, oil bodies granulate, not biconcentric, $6-20$ per cell, leaves almost fixedly bilobed (with some exception of uppermost leaves), 2-3(5)-stratose nearbase.

SchistochilopsishyperarcticaKonstant.\&L.Söderstr. (Arctic to Hemiarctic, highly disjunctive).

8. Stem 1.1-1.5 times wider than thick, oil bodies more than 20 (if fewer than 20 then biconcentric, or nonbiconcentric if less than 6-7 per cell), leaves fixedly bilobed (then unistratose to base) or irregularly 2-4-lobed (then 1-6-stratose in base)

9. Leaves nearly fixedly bilobed, unistratose to base, oil bodies granulate, nonbiconcentric, relatively large (seems almost filling cell lumen), 4-7 per midleaf cell

(Hemiboreal Kurilopsis obscura Bakalin

9. Leaves irregularly 2-4-lobed, 1-6-stratose in base, oil bodies more than 8-10 per cell, not filling cell lumen ........... 10

10. Plants with golden brownish shoot apices, not blacken in herbarium, 1-2-stratose in the base, oil bodies less than 15 per midleaf cell, mostly biconcentric

Schistochilopsispacifica Bakalin

(Hemiarctic to Boreal Asian Pacific).

10. Plants with pale green apices, without secondary pigmentation, blacken in herbarium, (2)3-5(6)-stratose at the base, oil bodies more than 20 permidleaf cell

Schistochilopsis opacifolia (Culm.) Konstant. (Arctic to Hemiarctic, also montane, circumpolar).

\section{ACKNOWLEDGEMENTS}

Line drawing were kindly compiled by Mr. M.A. Bakalin, to whom authors are sincerely grateful. Authors thank two anonymous reviewed for constructive comments. The work was partially supported by the grant from the Russian Foundation for Basic Researches (n. 15-04-20101).

\section{LITERATURE CITED}

Konstantinova, N.A. \& A.A. Vilnet 2009. New taxa and new combinations in Jungermanniales (Hepaticae). Arctoa 18:65-67.

Vilnet, A.A., N.A. Konstantinova \& A.V. Troitsky 2008. Phylogeny and systematics of the genus Lophozia s. str. (Dumort.) Dumort. (Hepaticae) and related taxa from nuclear ITS1-2 and chloroplast trnL-F sequences. Molecular Phylogenetics and Evolution 47:403-418. 